\title{
Conceptualizing Motivational Factors of Educationists
}

\author{
Mubbsher M. Khan ${ }^{1} \&$ Hira T. Masood ${ }^{2}$ \\ ${ }^{1}$ Institute of Business Administration, Quaid-e-Azam Campus, University of the Punjab, Lahore, Pakistan \\ ${ }^{2}$ University of the Punjab, Lahore, Pakistan \\ Correspondence: Mubbsher M. Khan, Quaid-e-Azam Campus, University of the Punjab, Lahore, Pakistan. Tel: \\ 92-42-9923-0800. Fax: 92-42-9923-1259. E-mail: mubbsher.khan@ibapu.edu.pk \\ Received: May 28, 2013 \\ doi:10.5430/bmr.v2n2p88 \\ Accepted: June 13, $2013 \quad$ Online Published: June 14, 2013 \\ URL: http://dx.doi.org/10.5430/bmr.v2n2p88
}

\begin{abstract}
Aim of this research is to determine the relationship between rewards and work motivation of Public Sector College teachers. For this purpose, keeping in view Pakistan as an important member of emerging markets, a number of public sector colleges are selected from Pakistan. A Questionnaire was used to collect information from 200 respondents. It was composed of 37 items that measured rewards and overall motivation of academic staff. Rewards are measured using five dimensions namely: pay, working conditions, job security, work itself and recognition. Data analysis is done using correlations and regression techniques. Work itself and recognition had statistically strong positive and significant association with motivation of teachers. However weaker relationship is found with working conditions and pay. This study conducted upon college/university teachers can also be conducted upon school teachers and other sector organizations. Dimensions of rewards, other than the five, used in this study can also be taken to determine their association with motivation as well as impact of demographics on motivation. This study is of its very first type that is conducted in education sector of Pakistan. It infers that in education sector, intrinsic sources of motivation are valued more than extrinsic ones. Also the findings are in accordance of Herzberg (1959) theory which states that intrinsic factors i.e. motivators tend to motivate individuals whereas presence of extrinsic factors prevents them from dissatisfaction.
\end{abstract}

Keywords: Job involvement, motivation, pay, recognition, work itself, working condition

\section{Introduction}

Human Resource Management refers to the management of intellectual resources and focuses on fulfilling requirements of management. Needs and wants of workers can be met through well-organized management (Torrington \& Hall, 1998). Today, the most valuable aspect for the economic stability of a country is the knowledge and competence of employees. These human skills come from job satisfaction and motivation that enable employees to carry out their routine tasks effectively (Litschka, Markom, \& Schunder, 2006). To enable workers to get motivated, managers must understand the trends that mould their behavior (Hanson \& Miller Jr, 2002).

The term "motivation" originated from the Latin word "movere" which mean to make some movement (Kreitner \& Kinicki, 2004). Over the years, many analysts have defined it in a variety of ways. They are of the view that it is the behavior intended towards a specific aim. We can define motivation as "internal and external factors that inspire the eagerness and enthusiasm in individuals to be devoted towards a task and to make constant exertion to accomplish that task." (Shafiq, Mariam, \& Raza, 2011). Aim of this research is to determine the relationship between rewards and work motivation of Public Sector College teachers. For this purpose, keeping in view Pakistan as an important member of emerging markets, a number of public sector colleges are selected from Pakistan.

In subsequent sections the researchers present a brief literature about a number of concerned areas, then come the methods employed to delineate the proposed research model, the hypotheses, research design and sampling design and finally the results, discussions and conclusion.

\section{Material Studied}

Motivation of employees is thought to be the most important objective of human resource practitioners as approximately all of them have basic intention to instill in them a feeling of commitment, devotion and satisfaction towards their work (Jerris, 1999). Lawler (1973) was of the view that motivation is the best predictor of employee performance. (Robbins, 2001) defined motivation as the "a person's interest to make high level of exertion to accomplish organizational goals, conditioned by effort's capability to fulfill an individual's need". Motivation is 
basically an internal force (Pepitone \& Bruce, 1998). It is a tool that leads human behavior towards satisfaction of his desires and wants (Schuler, 1998). Nohria, Groysberg, and Lee (2008) found that motivation can be determined by variety of factors that include retention, commitment and satisfaction. Many theories have been developed concerning motivation of employees.

A lot of work has been done in the literature concerning motivational factors. In order to maximize the performance of employees, organizations must formulate such policies, procedures and reward system which would improve employees' satisfaction and motivation. Performance of an organization depends upon the performance of its employees. Employees' rewards and incentives can be the tools for improving their performance.

Several theories have been developed by various analysts relating to employees' motivation towards work. These theories are still widely implemented in various organizations. These involve content as well as process theories. Content theories are based upon such elements that exist inside human beings that tend to motivate them and describe the reason behind changing needs of a person with the passage of time, whereas process theories provide description of behavior that is evolved by a person. These are explained below.

\subsection{Area Descriptions}

\subsubsection{Maslow's Hierarchy of Needs}

Abraham Maslow (1954) developed a theory called Hierarchy of Needs. He identified five levels of needs in the hierarchy and displayed these in the form of a pyramid with the most fundamental needs at the bottom and the need for self-actualization at the top of pyramid. It includes the physiological needs (food, shelter for living and certain material wants); safety and security needs (protection from physical and mental destruction); social needs (sense of affection, concern, belongingness and friendship with others); self-esteem (acknowledgement and admiration); and self-actualization need (to have those rights which a person deserves).

\subsubsection{Theory $\mathrm{X}$ and theory $\mathrm{Y}$}

This theory was developed by (McGregor, 1960). According to theory X, organization considers that its employees are very idle and lethargic. Moreover managers consider that their employees do not like to work, they usually avoid performing their duties, and they have no aim to flourish in life. According to theory Y, supervisors believe that employees are energetic, active; self-determined and implement willpower. They assume that employees enjoy their job, they take it as a challenge, and they don't take it as a burden, try their best to complete their tasks within the limited time and are goal oriented.

\subsubsection{Herzberg's Two Factor Theory}

Herzberg (1959) proposed a theory in which he differentiated between factors of satisfaction and factors of dissatisfaction at work, known as Two Factor theory. Herzberg broadened the theory that was proposed by Abraham Maslow. He carried out a study that revealed factors that caused satisfaction and dissatisfaction among employees. He divided the factors causing satisfaction and dissatisfaction into motivators and hygiene factors. Motivators involved recognition, advancement, growth etc. i.e. the factors that caused intrinsic satisfaction. Hygiene factors involved working environment, company policy, supervisor support etc. i.e. the factors that are associated with job dissatisfaction when they are not present, but their presence do not make employees much satisfied.

\subsubsection{Three Needs Theory}

McClelland (1961) developed a theory in which he states that every human being requires to have met three fundamental needs that play a very important role in motivating them during their work. These needs involve achievement, affiliation and power. Individuals that have high needs for achievement have passion to succeed and go beyond others. They prefer to perform task in such a manner that has never been accomplished before by anyone. Individuals that have high affiliation needs prefer to work with others, they like to make friends and want a companionship of others. Individuals having high needs for power desire to get hold of others, they want to supervise and control others and to lead them in the direction they desire to take them.

\subsubsection{Goal-Setting Theory}

Locke (1960) proposed a theory known as Goal Setting Theory. This theory states that goals lead towards improvement in employee performance. Bottom-line of this theory is that employee performance increases when they try to achieve some specific goals rather than pursuing general goals. Moreover by setting complex goals, employee motivation increases which results in increased performance.

\subsubsection{Reinforcement Theory}

Skinner (1953) proposed a theory which states that human behavior depends upon the consequences that caused it. "Reinforcement is a term in operant conditioning" ("Reinforcement," 2013, para. 1), "which is a type of learning in which an individual's behavior is modified by its consequences" ("Operant conditioning," 2013, para. 1).The central operators of operant conditioning are reinforcement and punishment which are either positive or negative, "This creates a total of four basic consequences in operant conditioning, with the addition of a fifth procedure known as extinction" ("Operant conditioning," 2013, "Reinforcement," para. 1). 
The behavior of manager towards employees is said to be a positive reinforcement (reinforcement) when it is followed (stimulated) by employees' behavior (e.g. good performance)that is rewarding (pleasant).If the employees' behavior (e.g. poor performance) sends a aversive (unpleasant) stimulus to the manager, the manager will try to remove it by employing more strict policies. If only by doing so improves the performance, the manager will continue to adopt more strict policies, this is known as negative reinforcement (escape).A punishment (e.g. reducing bonus of certain employees) incase these employees are not performing well after receiving bonus will be considered as positive punishment (punishment) when after it is being done by manager results in better performance by those employees in future. A punishment (e.g. demoting an employee) in case the employee does something that is against the rules and regulations of the organization will be considered as negative punishment (penalty) when after it is being done by manager results in avoiding such mistakes by that employee in future. Extinction occurs when management has to withdraw a set of newly implemented improvement policies or restrictions because such policies or restrictions are bringing no improvement in the organization.

\subsubsection{Expectancy Theory}

This theory was proposed by Victor Vroom (1964).He introduced new concepts of Valence, Instrumentality and Expectancy. Expectancy refers to the certainty that the work performed by individual would help him to achieve desired performance. Instrumentality refers to such a condition in which a person is sure that he will receive a reward if he performs well. Valence refers to the worth that an individual places to rewards earned by him.

\subsubsection{Equity Theory}

This theory was developed by John Stacy Adams in 1963.This theory states that employees should receive same and equal rewards as those received by their peers. He said that employees demand fairness between the efforts they are putting in and the results they are getting against these efforts and the output of their colleagues. This theory implies that an employee gets motivated when he believes that his mates are also getting the same reward as they are getting.

Literature reveals that numerous studies have been carried out on motivational factors of employees. Monetary rewards have seen to be the most important motivator for employees; no other reward contributes as effectively as money does (Rynes, Gerhart, \& Minette, 2004). But according to Fuhrmann (2006), salary is not the only factor that helps employees to get motivated; there are other factors as well e.g. advancement, feedback, participation in decision making etc. A study carried out by Danish and Usman (2010) on private sector employees of Pakistan reveals that rewards and recognition have a positive impact on employee work motivation. Similarly a research conducted by Manzoor (2012) concludes that empowerment and recognition have significant impact on employee work motivation. A study was conducted by Bosompem, Kwarteng, and Obeng-Mensah (2012) that investigated the relationship between levels of motivation, job satisfaction, supervision, work conditions, recognition, promotion, involvement in goal setting among agricultural science teachers of selected Senior High Schools in Central Region of Ghana. He found that the best determinants of teacher motivation are recognition and working conditions.

\section{Methods}

\subsection{Research Model}

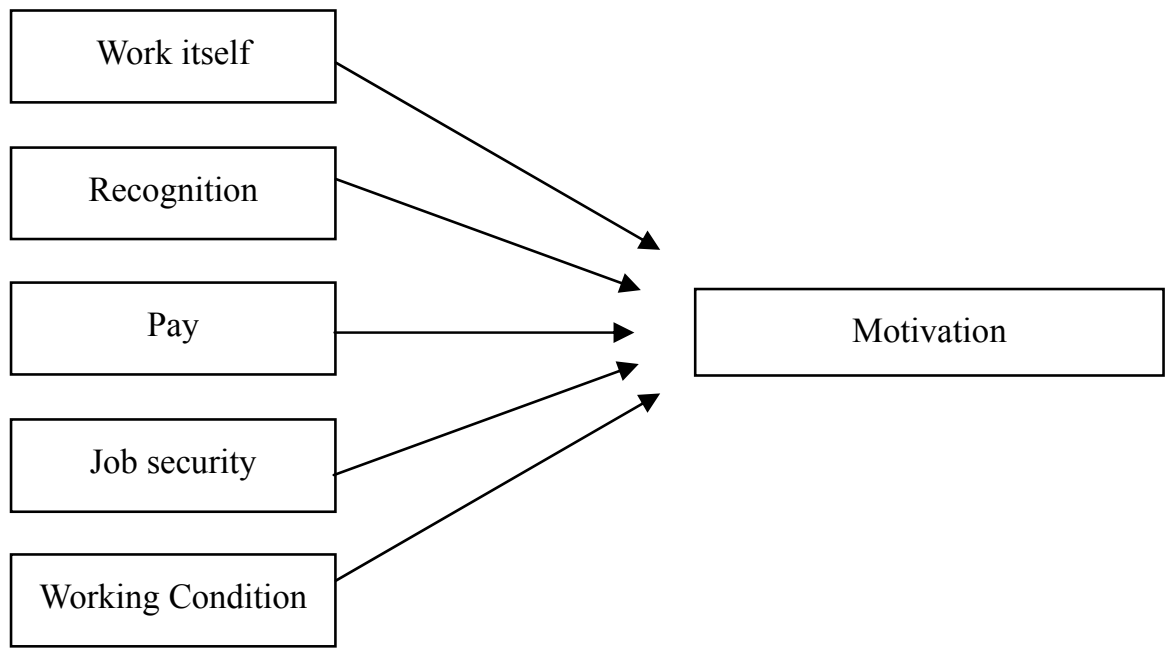

Figure 1. Research Model 


\subsection{Hypotheses}

H1: Work itself has positive and significant relationship with work motivation of academic staff

H2: Recognition has positive and significant relationship with work motivation of academic staff

H3: Pay has positive and significant relationship with work motivation of academic staff

H4: Job security has positive and significant relationship with work motivation of academic staff

H5: Working condition has positive and significant relationship with work motivation of academic staff

\section{Research Design and Sampling Design}

Sample size consists of 200 academicians from four public sector colleges in Pakistan. Convenience sampling is preferred in the current study. Information from respondents is collected through a structured questionnaire. The items for measuring the independent variables in the above model are adapted from three questionnaires: DeBeer (1987) "Work Satisfaction and Motivation questionnaire", Minnesota Satisfaction Questionnaire (1967) (MSQ), whereas items for measuring overall motivation are adapted from Salanova and Kirmanen (2010) questionnaire. Rating of the questionnaire was based on a five point Likert scale ranging from strongly agree to strongly disagree consisting of scores from 1 to 5, where 1 denotes strongly disagree and 5 denotes strongly agree. A 37 items questionnaire was developed which was brought in its final shape after the approval of the supervisor. To determine its reliability, a pilot study was conducted on fifteen respondents. From which the value of Cronbach's alpha turned out to be 0.737 . SPSS 16 is used for data analysis.

\section{Results}

All the data obtained through questionnaires was analyzed through the computer program namely SPSS Statistics by using different techniques.

Table 1. Demographics

\begin{tabular}{llll}
\hline \multirow{2}{*}{ Gender } & & Frequency & Percentage \\
\hline \multirow{3}{*}{ Age Category(Years) } & Male & 72 & 36 \\
& Female & 128 & 64 \\
\hline \multirow{2}{*}{ Marital Status } & $26-30$ & 93 & 60.5 \\
& $45-38$ & 66 & 26.5 \\
& Single & 27 & 13 \\
\hline \multirow{3}{*}{ Experience (Years) } & Married & 93 & 46.5 \\
& $1-5$ & 107 & 53.5 \\
\hline \multirow{3}{*}{ Level of job } & $6-16$ & 27 & 73 \\
& $20-27$ & 27 & 13.5 \\
& Lecturer & 125 & 13.5 \\
\hline \multirow{2}{*}{ Qualification } & Asst. Professor & 28 & 72.5 \\
& Asso. Professor & 27 & 14 \\
& Bachelors & 40 & 13.5 \\
\hline
\end{tabular}

Table 1 show that $36 \%$ of academic staff is comprised of males whereas $64 \%$ involve females.

Respondents falling in the age category of 26-30 years comprise $60.5 \%$ of total; those falling in 32-38 years category are $26.5 \%$, whereas the ones falling in $45-50$ years category are $13 \%$. Respondents who were unmarried comprise $46.5 \%$, those married are $53.5 \%$. Respondents having experience of $1-5$ years are $73 \%$, those having $6-16$ years' experience are $13.5 \%$, whereas the ones having 20-27 years' experience make up $13.5 \%$. $72.5 \%$ are lecturers, $14 \%$ are Assistant Professors while 13.5\% are associate professors. 20\% are composed of bachelors, $60 \%$ masters and $20 \%$ M. Phil. 
Table 2. Descriptive statistics

\begin{tabular}{llll}
\hline Variables & $\mathrm{N}$ & Mean & Std. Deviation \\
Job security & 200 & 4.4150 & .32237 \\
Work itself & 200 & 3.8810 & .23985 \\
Working conditions & 200 & 3.8750 & .55460 \\
Pay & 200 & 2.7388 & .63419 \\
Recognition & 200 & 1.9500 & .35355 \\
\hline
\end{tabular}

Table 2 shows mean and standard deviation of the factors of motivation. It can be seen that job security has a mean value of 4.4150 which is greater than the neutral value i.e. 3.It indicates that teachers agree job security has an impact on their motivation level. Similarly work itself and working condition have mean value of 3.8810 and 3.8750 respectively which are also greater than the neutral value, indicating that work itself and working conditions too have impact on their motivation level. Pay and recognition have mean values of 2.7388 and 1.9500 respectively which are lower than 3. It indicates they disagree that pay and recognition motivate them.

Table 3. Correlations

\section{Correlations}

\begin{tabular}{|c|c|c|c|c|c|c|c|}
\hline & & $\begin{array}{l}\text { Work } \\
\text { itself }\end{array}$ & Recognition & Pay & $\begin{array}{c}\text { Job } \\
\text { security }\end{array}$ & $\begin{array}{l}\text { Working } \\
\text { condition }\end{array}$ & Motivation \\
\hline \multirow{3}{*}{$\begin{array}{l}\text { Intrinsic } \\
\text { Rewards }\end{array}$} & Work itself & 1 & $-.165^{*}$ & $.475^{* *}$ & $.418^{* *}$ & $.449^{* *}$ & $.579^{* *}$ \\
\hline & Recognition & & 1 & $.219^{* *}$ & $-.142^{*}$ & $-.164^{*}$ & $.374^{* *}$ \\
\hline & Pay & & & 1 & .112 & $.307^{* *}$ & $.312^{* *}$ \\
\hline \multirow{3}{*}{$\begin{array}{l}\text { Extrinsic } \\
\text { Rewards }\end{array}$} & Job security & & & & 1 & $.758^{* *}$ & $.349^{* *}$ \\
\hline & $\begin{array}{l}\text { Working } \\
\text { condition }\end{array}$ & & & & & 1 & $.279^{* *}$ \\
\hline & Motivation & & & & & & 1 \\
\hline
\end{tabular}

**. Correlation is significant at the 0.01 level (2-tailed)

*. Correlation is significant at the 0.05 level (2-tailed)

The correlations between all possible pairs of variables are given in the table 3 . The hypotheses of this research are now discussed here based on the findings of correlation analysis. The hypotheses 1 and 2 relate to the intrinsic rewards and cover two main variables that are work itself and recognition. Here they are having positive and significant relationship with employee work motivation. It can be seen from the table that work itself had a correlation coefficient of $.579^{* *}$, significant at .001 level. Also recognition had a correlation coefficient of .374**, Significant at .001 level. Work itself and recognition showed a significant positive relationship with employee work motivation. Thus the hypotheses 1 and 2 are proved.

The hypotheses 3, 4 and 5 relate to the extrinsic rewards and cover three main variables: pay, job security and working condition. Here these variables show positive and significant relationship with employee work motivation. It can be seen from the table that pay had a correlation coefficient of $.312^{* *}$, significant at .001 level, job security had a correlation coefficient of .349**, significant at .001 level and working condition had a correlation coefficient of $.279^{* *}$, significant at .000 levels. The correlation values for these variables are showing a significant positive relationship with employee work motivation. Thus the hypotheses 3, 4 and 5 are also proved.

Tables, 4, 5 and 6 show results of the regression analysis: 
Table 4. Regression Analysis

\begin{tabular}{lcccc}
\hline & \multicolumn{2}{c}{ Regression Analysis } \\
& $\mathbf{R}$ & $\mathbf{R}^{\mathbf{b}}$ & $\boldsymbol{\beta}$ & $\boldsymbol{\rho}$ \\
Work Itself & $.579^{* *}$ & .336 & .556 & .000 \\
Recognition & $.374^{* *}$ & .192 & .173 & .005 \\
Job security & $.349^{* *}$ & .122 & .237 & .010 \\
Pay & $.312^{* *}$ & .098 & .023 & .005 \\
Working condition & $.279^{* *}$ & .078 & -.128 & .000 \\
\hline
\end{tabular}

a. Predictors: (Constant), Job Security, Pay, Recognition, Work itself, Working Condition

b. Dependent variable: Motivation

Table 4 shows that work itself has highest R-squared value of .336 which means that it explains $33.6 \%$ variation in motivation. Whereas lowest R-squared value is of working conditions i.e. .078 which is explaining only $7.8 \%$ variation in motivation.

Table 5. Model Summary

\begin{tabular}{|c|c|c|c|c|c|c|c|c|c|}
\hline \multicolumn{10}{|c|}{ Model Summary $^{b}$} \\
\hline Model & $\mathbf{R}$ & $\mathbf{R}^{2}$ & Adj $\mathbf{R}^{2}$ & S.E & $\mathbf{R}^{2}$ change & F change & df1 & df2 & Sig. F change \\
\hline 1 & $.623^{\mathrm{a}}$ & .389 & .373 & .13366 & .389 & 24.673 & 5 & 194 & .000 \\
\hline
\end{tabular}

a. Predictors: (Constant), Job Security, Pay, Recognition, Work itself, Working Condition

b. Dependent variable: Motivation

It can be seen in Model Summary table (Table 5), that the independent variables (predictors) that are entered into the regression model had a combined correlation of $(\mathrm{R}=.623)$ with the dependent variable motivation. The value of R-Squared (the coefficient of determination) is .389, which shows that the independent variables explained (38.9\%) of the variance in motivation.

Table 6. ANOVA

\begin{tabular}{lccccc}
\hline \multirow{2}{*}{ Model } & \multicolumn{5}{c}{ ANOVA $^{\mathbf{b}}$} \\
Regression & Sum of squares & df & Mean square & F & Sig. \\
Residual & 2.204 & 5 & .441 & 24.673 & $.000^{\text {a }}$ \\
\hline Total & 3.466 & 194 & .018 & \\
\hline
\end{tabular}

a. Predictors: (Constant), Job Security, Pay, Recognition, Work itself, Working Condition

b. Dependent variable: Motivation

The ANOVA analysis (Table 6) showed the F-value of 24.673 significant at .000 level. It means that the above model is $100 \%$ fit, that is there is a significant relation between entered independent variables and the dependent variable. Hence the regression analysis also validates all of our hypotheses as all of the independent variables are found to be significant at $1 \%$ level of significance.

\section{Discussions and Conclusion}

Aim of this research is to find association between motivation and different dimensions of motivation of teachers. Through correlation and regression analysis, it is found that all of the independent variables are positively and statistically significant with work motivation including work itself and recognition being the most significant. These results are in accordance with the findings of a large number of researchers who worked on work motivation of employees (Khan, Farooq, \& Khan, December 2010; Rasheed, Aslam, \& Sarwar, 2010; Goodin, 2003; Nadia, Syed, \& Humera, 2011; Ken, 2000; Khojasteh, 1993; Egwuridi, 1981). Since a lot of research has been done on the relationship between rewards and motivation, especially in private sector firms worldwide, through these studies, it can be observed that there has been a consistent trend towards increase in motivation level of workers through extrinsic sources of motivation (Nadia, Syed, \& Humera, 2011; Ajila \& Abiola, 2004; Pratheepkanth, 2011; 
Mahamuda Parvin \& Nurul Kabir, 2011; Chandrakesar, 2011; Bosompem, Adjei Kwarteng, \& Obeng-Mensah, 2012). Current study is an attempt to consider the impact of same factors in education sector of Pakistan because very little research has been done on Pakistani academicians regarding their motivation level (Bhatti, Rawat, \& Hamid, 2012; Javaid, 2009; Tariq, Hussain, \& Mahmood, 2011). It can be seen that intrinsic factors tend to motivate them more than extrinsic ones. Through this study, it can be inferred that in education sector, intrinsic sources of motivation are valued more than extrinsic ones. Our findings are in accordance of Herzberg (1959) theory which states that intrinsic factors i.e. motivators tend to motivate individuals whereas presence of extrinsic factors prevents them from dissatisfaction. So, in order to increase academician's level of motivation, they must be recognized for their work through promotions, salary raises etc. and must be provided with good and comfortable working conditions.

\section{Future Implications and Limitations of the study}

This study is based upon academic staff of colleges/universities. However, the same study can be conducted upon school teachers and other sector organizations. Five dimensions of rewards are taken to determine their association with motivation. Other factors such as promotion opportunities, relationship with peers, coworkers, support and help from manager etc., can also be included. Moreover the impact of demographics on motivation is not tested in this research.

\section{References}

Adelabu, M. (2005). Teacher motivation and incentives in Nigeria. Unpublished dissertation.

Ajila, C., \& Abiola, A. (2004). Influence of rewards on worker's performance in an organization. Journal of Social Sciences, 8 (1), 7-12.

Bhatti, T., Rawat, K. J., \& Hamid, S. (2012). Motivation crisis among primary school teachers: A descriptive study. American Journal of Scientific Research (51), 122-131.

Bosompem, M., Kwarteng, J. A., \& Obeng-Mensah, A. (January 2012). Determinants of motivation of senior high school agricultural science teachers in the Central Region, Ghana. International Journal of Public Administration and Management Research 1(1), 18-31. RCMSS/IJPAMR/12002

Chandrasekar, K. (2011). Workplace environment and its impact on organizational performance in public sector organizations. International Journal of Enterprise Computing and Business Systems 1(1).

Danish, R. Q., \& Usman, A. (2010). Impact of reward and recognition on job satisfaction and motivation: An empirical study from Pakistan. International Journal of Business and Management, 5(2), 159-167.

De Beer, M. (1987). 'n Ondersoek na die rol wat arbeidsomset in die bedryf speel met spesifieke verwysing na werkbevrediging en werksmotivering. Unpublished master's dissertation, University of the Free State, Bloemfontein.

Egwuridi, P. (1981). Job satisfaction: Effects on job characteristics. Unpublished MSc Dissertation University of Lagos, Nigeria.

Fuhrmann, T. (2006). Motivating Employees. WCDS Advances in Dairy Technology, 18, pp. 93-101.

Goodin, R. (2003). Democratic accountability: The third sector and all. Boston: Hauser Center for Nonprofit Organizations, Harvard University.

Hanson, M., \& Miller Jr, A. (2002). The productive use of strengths: A shared responsibility. Industrial and commercial training, 34 (3), 95-100. http://dx.doi.org/10.1108/00197850210424935

Herzberg, F. (1959). The motivation to work (2nd ed.). Wiley.

Javaid, N. (2009). Teacher motivation - An area of neglect. CIDA Pakistan Programme.

Jerris, L. A. (1999). Human resources management for hospitality. Prentice Hall.

Ken, G. (2000). Work motivation factors of the public sector and private sector convention centre employees. A Research paper submitted in partial fulfillment of the requirements of the Masters of Science Degree: University of Wisconsin-Stout.

Khan, K., Farooq, S. U., \& Ullah, M. I. (2010). The relationship between rewards and employee motivation in commercial banks of Pakistan. Research journal of international studies, 14, 37-52.

Khojasteh, M. (1993). Motivating the private vs. public sector managers. Public Personnel Management, 22 (3), 391-401. 
Kreitner, R., \& Kinicki, A. (2004). Organizational behavior (6th ed.). Boston,MA: McGraw-Hill, Irwin.

Lawler, E. E. (1973). Motivation in work organizations (Vol. 2). Brooks/Cole Pub. Co.

Litschka, M., Markom, A., \& Schunder, S. (2006). Measuring and analysing intellectual assets: An integrative approach. Journal of intellectual capital, 7 (2), 160-173. http://dx.doi.org/10.1108/14691930610661836

Locke, E. A. (1982). The ideas of Frederick W. Taylor: an evaluation. Academy of Management Review, 14-24.

Mahamuda Parvin, M., \& Nurul Kabir, M. M. (2011). Factors affecting employee job satisfaction of pharmaceutical sector. Australian Journal of Business and Management Research, 1 (9), 113-123.

Manzoor, Q. A. (2012). Impact of employees motivation on organizational effectiveness. Business Management and Strategy, 3(1), 1-12.

Maslow, A. H. (1954). Motivation and personality. New York: Harper \& Row Publishers, Inc.

McClelland, D. C. (1961). The Achieving Society. Princeton, New Jersey: D. Van Nostrand.

McGregor, D. (1960). The human side of enterprise. McGraw Hill.

Hafiza, N., Shah, S., Jamseheed, H., \& Zamam, K. (2011). Relationship between rewards and employee motivation in the non-profit organization of Pakistan. Business Intelligence Journal, 4(2), 327-334.

Nohria, N., Groysberg, B., \& Lee, L. (2008). Employee motivation: A powerful new model. Harvard Business Review, 86(7/8), 78.

Operant conditioning. (n.d.). In Wikipedia. Retrieved March 06, 2013, from http://en.wikipedia.org/wiki/Operant_conditioning

Pepitone, S. J., \& Bruce, A. (1998). Motivating employees (1st ed.). McGraw-Hill.

Pratheepkanth, P. (2011). Reward system and its impact on employee motivation in commercial bank of sri lanka plc, in jaffna district. Global Journal of Management And Business Research, 11(4).

Rasheed, M. I., Aslam, H. D., \& Sarwar, S. (2010). Motivational issues for teachers in higher education: A critical case of IUB. Journal of Management Research, 2 (2).

Reinforcement. (n.d.). In Wikipedia. Retrieved March 06, 2013, from http://en.wikipedia.org/wiki/Reinforcement

Robbins, S. P. (2001). Organizational behavior (9th ed.). Prentice Hall.

Rynes, S. L., Gerhart, B., \& Minette, K. A. (2004). The importance of pay in employee motivation: Discrepancies between what people say and what they do.Human Resource Management, 43(4), 381-394. http://dx.doi.org/10.1002/hrm.20031

Salanova, A., \& Kirmanen, S. (2010). Employee satisfaction and work motivation. Unpublished Bachelor Thesis, Mikkeli University of Applied Sciences, Finland.

Schuler, R. S. (1998). Managing Human Resources (6th ed.). Pennsylvania State University: South-Western College Publishing.

Shafiq, M., \& Naseem, M. (2011). Association between reward and employee motivation: A case study banking sector of Pakistan. Available at SSRN 1857663. http://dx.doi.org/10.2139/ssrn.1857663

Skinner, B. F. (1953). Science and human behavior. Pearson Education, Inc.

Tariq, S., Hussain, S., \& Mahmood, S. (2011). The relationship between intrinsic motivation and academic achievement of male and female students at university level in Pakistan: A case study. Journal of Education and Vocational Research, 2 (5), 154-161.

Torrington, D., \& Hall, L. (1998). Human resource management (4th ed.). Europe: Prentice Hall.

Vroom, V. (1964). Work and motivation. New York: Wiley. 